\title{
Current Situation of the Scientific Research Quality of Primary and Secondary School Teachers in Henan Province and Its Countermeasures under the Background of Knowledge Transformation
}

\author{
Xiang Ma \\ Huanghe Science and Technology College \\ Zhengzhou, China
}

\begin{abstract}
At the turn of this century, the new basic education reform has begun in our country, of which the core is curriculum reform. The new curriculum reform has great changes in teaching ideas, teaching contents and teaching methods. Firstly, the value orientation of the basic education curriculum has significant change. All contents and measures of the reform are student-oriented, paying more attention to the independent development of students. The value orientation of the Outline and the Interpretation is "generic humanistic". In the new curriculum reform, the teachers no longer teach according to the plan designed by experts. The curriculum reform of elementary education requires the primary and secondary school teachers to not only "teach" but also "research", bringing challenges and development for the scientific research of the primary and secondary school teachers.
\end{abstract}

Keywords-knowledge transformation; the primary and secondary school teachers; scientific research

\section{INTRODUCTION}

Under the background of knowledge transformation, research on the 4855 teachers of 185 middle and primary schools in Xin'an county of Henan province, investigate the age, the professional title structure, the education background, quantity and the current situation of scientific research of them and interview the school administrators through the visiting survey as well as record and conclude the interview contents; know about the current situation of scientific research quality of school administrators and teachers through the questionnaire method (questionnaires distributed to school administrators and teachers) systematically, and objectively analyze the problems in it. According to the above analysis result, ways used to solve the problems in restricting the scientific research quality of primary and secondary school teachers of Xin'an county of Henan province are proposed, providing valuable references for related departments to take action. 4855 questionnaires are distributed in total with 4,500 valid questionnaires, and the effective rate of recovery is $92.7 \%$.

This paper is the phased research fruit of the educational curriculum reform research project of teachers for the Education Department of Henan province, project number: 2014-JSJYYB-145.

\section{INVESTIGATION ON THE CURRENT SITUATION OF} EDUCATIONAL SCIENTIFIC RESEARCH CARRIED OUT BY PRIMARY AND SECONDARY SCHOOL TEACHERS

According to the statistics, there are 7292 faculties in middle and primary schools of Xin' an County with 4855 fulltime faculties; 792 faculties in senior high schools with 718 full-time faculties; 940 faculties in vocational schools with 817 full-time faculties; 1383 faculties in junior high schools with full-time faculties of 1301; 2017 faculties in primary schools with full-time faculties of 1954; 231 teachers have the title of a senior professional post and 1669 teachers have the mediumgrade professional title. It is shown as follows "Table I".

TABLE I. SCHOOL PERSONAL Distribution

\begin{tabular}{lcccc}
\hline Category & $\begin{array}{c}\text { Senior } \\
\text { high school }\end{array}$ & $\begin{array}{c}\text { Vocational } \\
\text { school }\end{array}$ & $\begin{array}{c}\text { Junior } \\
\text { high school }\end{array}$ & $\begin{array}{c}\text { Primary } \\
\text { school }\end{array}$ \\
\hline Total faculty & 792 & 940 & 1383 & 2017 \\
Full-time faculty & 718 & 817 & 1301 & 1954 \\
\hline
\end{tabular}

A. The Requirements of the School for Teachers' Educational Scientific Research

TABLE II. REQUIREMENTS OF THE SCHOOL FOR THE TEACHERS EDUCATIONAL SCIENTIFIC RESEARCH

\begin{tabular}{lccc}
\hline Option & $\begin{array}{c}\text { Have clear } \\
\text { de mand }\end{array}$ & $\begin{array}{c}\text { Have demand, } \\
\text { but not put into practice }\end{array}$ & Have no demand \\
\hline $\begin{array}{l}\text { Number } \\
\text { Proportion }\end{array}$ & 2200 & 2000 & 300 \\
& $48.9 \%$ & $44.4 \%$ & $6.7 \%$ \\
\hline
\end{tabular}

As shown in "Table II": most schools have demands for teachers' educational scientific research. $48.9 \%$ of teachers (2200) choose "have clear demand"; $44.4 \%$ of teachers $(2000)$ choose "have demand, but not put into practice"; only $6.7 \%$ of teachers (600) choose "have no demand". According to the data, we find most schools have demands for teachers' educational scientific research, but most teachers think it rests on the oral propaganda instead of implementation. 
B. The Forms of the Schools Organizing and Guiding Educational Scientific Research

TABLE III. FORMS USED BY THE SCHOOL TO ORGANIZE AND GUIDE THE EDUCATIONAL SCIENTIFIC RESEARCH

\begin{tabular}{llcc}
\hline Option & Expert guidance & $\begin{array}{c}\text { Guidance of the school, } \\
\text { teaching and research offices }\end{array}$ & No guidance \\
\hline $\begin{array}{l}\text { Number } \\
\text { Proportion }\end{array}$ & 410 & 2300 & 1790 \\
\hline
\end{tabular}

$9.1 \%$ of teachers (410) choose "expert guidance"; $51.1 \%$ of teachers (2300) choose "guidance of the school, teaching and research offices"; $39.8 \%$ of teachers (1790) choose "no guidance". It shows the forms to guide the primary and secondary school teachers' educational scientific research are single. The most prominent problem is the lack of professional guidance capability "Table III".

\section{The Atmosphere of Educational Scientific Research in Primary and Secondary Schools}

TABLE IV. ATMOSPHERE OF EDUCATIONAL SCIENTIFIC RESEARCH IN MIDDLE AND PRIMARY SCHOOLS

\begin{tabular}{llll}
\hline Option & $\begin{array}{l}\text { Most teachers } \\
\text { engage in the } \\
\text { educational } \\
\text { scientific } \\
\text { research with } \\
\text { strong } \\
\text { atmosphere }\end{array}$ & $\begin{array}{l}\text { Some teachers } \\
\text { educational in the } \\
\text { scientific research } \\
\text { with general } \\
\text { atmosphere }\end{array}$ & $\begin{array}{l}\text { Only several people } \\
\text { or no one engage in } \\
\text { the educational } \\
\text { scientific research } \\
\text { with atmosphere } \\
\text { atmeak }\end{array}$ \\
\hline $\begin{array}{l}\text { Number of } \\
\text { persons } \\
\text { Proportion }\end{array}$ & $\begin{array}{l}1287 \\
28.6 \%\end{array}$ & 2763 & 450 \\
\hline
\end{tabular}

According to the analysis results "Table IV", $28.6 \%$ of teachers (1287) choose "most teachers engage in the educational scientific research with strong atmosphere"; $61.4 \%$ of teachers (2763) choose "some teachers engage in the educational scientific research with general atmosphere"; $10 \%$ of teachers (450) choose "only several people or no one engage in the educational scientific research with weak atmosphere". It shows most primary and secondary school teachers are not satisfied with the weak atmosphere of educational scientific research in the school.

\section{FROM THE PERSPECTIVE OF TEACHERS}

\section{A. The Cognition of Primary and Secondary School Teachers forEducational Scientific Research}

TABLE V. THE COGNITION OF PRIMARY AND SECONDARY SCHOOL TEACHERS FOR THE EDUCATIONAL SCIENTIFIC RESEARCH

\begin{tabular}{|c|c|c|c|c|}
\hline Option & $\begin{array}{l}\text { The } \\
\text { education } \\
\text { al } \\
\text { scientific } \\
\text { research is } \\
\text { very } \\
\text { important. }\end{array}$ & $\begin{array}{l}\text { The } \\
\text { educational } \\
\text { scientific } \\
\text { research is } \\
\text { important } \\
\text { but } \\
\text { unnecessary. }\end{array}$ & $\begin{array}{l}\text { The educational } \\
\text { scientific research } \\
\text { should be done } \\
\text { by experts and } \\
\text { scholars and has } \\
\text { no relationship } \\
\text { with them }\end{array}$ & $\begin{array}{l}\text { The } \\
\text { educational } \\
\text { scientific } \\
\text { research is } \\
\text { unimportan } \\
\text { t. }\end{array}$ \\
\hline $\begin{array}{l}\text { Number } \\
\text { of } \\
\text { persons }\end{array}$ & 1638 & 1904 & 756 & 202 \\
\hline $\begin{array}{l}\text { Proporti } \\
\text { on }\end{array}$ & $36.4 \%$ & $42.3 \%$ & $16.8 \%$ & $4.5 \%$ \\
\hline
\end{tabular}

According to the investigation on teachers' attitudes toward the educational scientific research "Table V", 36.4\% of teachers (1638) think "the educational scientific research is very important"; $42.3 \%$ of teachers (1904) think "the educational scientific research is important but unnecessary"; $16.8 \%$ of teachers (756) think "the educational scientific research should be done by experts and scholars and has no relationship with them"; $4.5 \%$ of teachers (202) think "the educational scientific research is unimportant". It shows many teachers cannot understand the significance and effect of the educational scientific research very well at present because of the influence of the traditional educational ideas. They haven't connected the educational scientific research with the education and teaching but regard it as the responsibility of others. It will have a negative influence on working on the educational scientific research.

TABLE VI. ThE COGNITION OF PRIMARY AND SECONDARY SCHOOL TEACHERS FOR THE EDUCATIONAL SCIENTIFIC RESEARCH

\begin{tabular}{|c|c|c|c|}
\hline Option & $\begin{array}{lr}\text { Never } & \text { think } \\
\text { about } & \text { the } \\
\text { educational } & \\
\text { scientific } & \\
\text { research } & \end{array}$ & $\begin{array}{l}\text { Occasionally } \\
\text { think about the } \\
\text { educational } \\
\text { scientific research }\end{array}$ & $\begin{array}{lr}\text { Frequently } & \text { think } \\
\text { about } & \text { the } \\
\text { educational } & \\
\text { scientific } & \\
\text { research } & \end{array}$ \\
\hline $\begin{array}{l}\text { Number of } \\
\text { persons }\end{array}$ & 1372 & 2088 & 1040 \\
\hline Proportion & $30.5 \%$ & $46.4 \%$ & $23.1 \%$ \\
\hline
\end{tabular}

In regard to the consciousness of teachers, $30.5 \%$ of teachers (1372) "never think about the educational scientific research"; $46.4 \%$ of teachers (2088) "occasionally think about the educational scientific research"; $23.1 \%$ of teachers (1040) frequently think about the educational scientific research. It reflects not too many teachers have the strong consciousness to do educational scientific research "Table VI".

TABLE VII. THE COGNITION OF PRIMARY AND SECONDARY SCHOOL TEACHERS FOR THE EDUCATIONAL SCIENTIFIC RESEARCH

\begin{tabular}{llll}
\hline Option & $\begin{array}{l}\text { Work on the } \\
\text { educational } \\
\text { scientific research } \\
\text { under external } \\
\text { pressure }\end{array}$ & $\begin{array}{l}\text { Work on the } \\
\text { educational } \\
\text { scientific research } \\
\text { because of the } \\
\text { internal interests } \\
\text { and needs }\end{array}$ & $\begin{array}{l}\text { Follow the trend } \\
\text { to work on the } \\
\text { educational } \\
\text { scientific } \\
\text { research }\end{array}$ \\
\hline $\begin{array}{l}\text { Number of } \\
\text { persons } \\
\text { Proportion }\end{array}$ & 2002 & 1062 & 1435 \\
\hline
\end{tabular}

In regard to the motivations of teachers "Table VII", $44.5 \%$ of teachers (2002) "work on the educational scientific research under external pressure"; $23.6 \%$ of teachers (1062) "work on the educational scientific research because of the internal interests and needs"; $31.9 \%$ of teachers (1435) "follow the trend to work on the educational scientific research". It reflects the primary and secondary school teachers at present work on the educational scientific research because of external pressures and requirements instead of internal needs. 
B. Value Orientation of the Primary and Secondary School Teachers in Working on the Educational Scientific Research

TABLE VIII. VALUE ORIENTATION OF THE PRIMARY AND SECONDARY SCHOOL TEACHERS IN WORKING ON THE EDUCATIONAL SCIENTIFIC RESEARCH

\begin{tabular}{|c|c|c|c|c|c|c|}
\hline Option & $\begin{array}{l}\text { Dem } \\
\text { ands } \\
\text { of } \\
\text { scho } \\
\text { ol } \\
\text { lead } \\
\text { ers }\end{array}$ & $\begin{array}{l}\text { The } \\
\text { needs of } \\
\text { conferri } \\
\text { ng } \\
\text { professi } \\
\text { onal } \\
\text { titles } \\
\text { and } \\
\text { assessm } \\
\text { ent }\end{array}$ & $\begin{array}{l}\text { I have to } \\
\text { do the } \\
\text { educatio } \\
\text { nal } \\
\text { scientifi } \\
\text { c } \\
\text { research } \\
\text { because } \\
\text { others } \\
\text { work on } \\
\text { it. }\end{array}$ & $\begin{array}{l}\text { To } \\
\text { impro } \\
\text { ve } \\
\text { the } \\
\text { teachi } \\
\text { ng } \\
\text { qualit } \\
y\end{array}$ & $\begin{array}{l}\text { Do the } \\
\text { educatio } \\
\text { nal } \\
\text { scientifi } \\
\text { c } \\
\text { research } \\
\text { to } \\
\text { improve } \\
\text { self- } \\
\text { quality }\end{array}$ & $\begin{array}{l}\mathrm{Be} \\
\text { intereste } \\
\mathrm{d} \text { in the } \\
\text { educatio } \\
\text { nal } \\
\text { scientific } \\
\text { research }\end{array}$ \\
\hline $\begin{array}{l}\text { Numbe } \\
\mathbf{r \quad \text { of }} \\
\text { person } \\
\mathrm{S}\end{array}$ & 490 & 877 & 779 & 900 & 940 & 513 \\
\hline $\begin{array}{l}\text { Propor } \\
\text { tion }\end{array}$ & $\begin{array}{l}10.9 \\
\%\end{array}$ & $19.5 \%$ & $17.3 \%$ & $20 \%$ & $20.9 \%$ & $11.4 \%$ \\
\hline
\end{tabular}

The results show "Table VIII": $10.9 \%$ of teachers (490) work on the educational scientific research because of "demands of school leaders"; $19.5 \%$ of teachers $(877)$ work on the educational scientific research because of "the needs of conferring professional titles and assessment"; $17.3 \%$ of teachers (779) think "I have to do the educational scientific research because others work on it"; $20 \%$ of teachers (900) do the educational scientific research "to improve the teaching quality"; $20.9 \%$ of teachers (940) "do the educational scientific research to improve self-quality"; $11.4 \%$ of teachers (513) do the educational scientific research because of "being interested in the educational scientific research". It reflects the diversification of primary and secondary school teachers' value orientation in educational scientific research and the strong utilitarian color. Few teachers do educational scientific researches to improve self-quality and teaching quality.

\section{Primary and Secondary School Teachers' Ability and Level in Working on the Educational Scientific Research}

TABLE IX. PRIMARY AND SECONDARY SCHOOL TEACHERS' ABILITY AND LEVEL IN WORKING ON THE EDUCATIONAL SCIENTIFIC RESEARCH

\begin{tabular}{|c|c|c|c|c|}
\hline Option & $\begin{array}{l}\text { Know the } \\
\text { concept of the } \\
\text { educational } \\
\text { scientific } \\
\text { research }\end{array}$ & $\begin{array}{lr}\text { Know } & \text { and } \\
\text { grasp } & \text { the } \\
\text { meanings } & \text { of } \\
\text { standard } & \\
\text { deviation } & \text { and } \\
\text { correlation } & \\
\text { index } & \text { and } \\
\text { common } & \\
\text { research } & \\
\text { methods } & \\
\end{array}$ & $\begin{array}{l}\text { Know the } \\
\text { basic } \\
\text { process of } \\
\text { scientific } \\
\text { research }\end{array}$ & $\begin{array}{l}\text { Be } \\
\text { familiar } \\
\text { with } \\
\text { pedagogy, } \\
\text { psycholog } \\
\text { y and } \\
\text { discipline }\end{array}$ \\
\hline $\begin{array}{l}\text { Numbe } \\
\mathbf{r} \text { of } \\
\text { person } \\
s\end{array}$ & 1719 & 1165 & 923 & 693 \\
\hline $\begin{array}{l}\text { Propor } \\
\text { tion }\end{array}$ & $38.2 \%$ & $25.9 \%$ & $20.5 \%$ & $15.4 \%$ \\
\hline
\end{tabular}

In grasping the theories of educational scientific research, $38.2 \%$ of teachers (1719) "know the concept of the educational scientific research"; $25.9 \%$ of teachers (1165) "know and grasp the meanings of standard deviation and correlation index"; 20.5\% of teachers (923) "know the basic process of educational scientific research and common research methods"; $15.4 \%$ of teachers (693) "are familiar with pedagogy, psychology and subject teaching approach". It shows theories especially some specialized knowledge related to the educational scientific research lack in primary and secondary school teachers' knowledge structure, namely their knowledge literacy of educational scientific research is low "Table IX".

TABLE $X$ PRIMARY AND SECONDARY SCHOOL TEACHERS' ABILITY AND LEVEL IN WORKING ON THE EDUCATIONAL SCIENTIFIC RESEARCH

\begin{tabular}{lllll}
\hline Option & $\begin{array}{l}\text { Can find out } \\
\text { topics on the } \\
\text { educational } \\
\text { scientific } \\
\text { research } \\
\text { frequently }\end{array}$ & $\begin{array}{l}\text { Can find out } \\
\text { topics on the } \\
\text { educational } \\
\text { scientific } \\
\text { research }\end{array}$ & $\begin{array}{l}\text { It hard to find } \\
\text { out topics on } \\
\text { the educational } \\
\text { scientific } \\
\text { research }\end{array}$ \\
\hline $\begin{array}{l}\text { Number of } \\
\text { persons } \\
\text { Proportion }\end{array}$ & $\begin{array}{l}1003 \\
22.3 \%\end{array}$ & 2147 & 1350 \\
\hline
\end{tabular}

According to the investigation on the primary and secondary school teachers' ability in finding topics on the educational scientific research, $22.3 \%$ of teachers (1003) can find out topics on the educational scientific research frequently"; $47.7 \%$ of teachers (2147) "can find out topics on the educational scientific research"; $30 \%$ of teachers $(1350)$ think "it is hard to find out topics on the educational scientific research" "Table X". It shows most primary and secondary school teachers cannot timely, scientifically and effectively find out problems worthy of researching in education, and ability and level of them in educational scientific research are low "Table X".

TABLE XI. SELF-EVALUATION ON THE ABILITY AND LEVEL IN EDUCATIONAL SCIENTIFIC RESEARCH

\begin{tabular}{llll}
\hline Option & High & Medium & Low \\
\hline $\begin{array}{l}\text { Number of } \\
\text { persons }\end{array}$ & 1246 & 1678 & 1575 \\
Proportion & $27.7 \%$ & $37.3 \%$ & $35 \%$ \\
\hline
\end{tabular}

Only $27.7 \%$ of teachers (1246) think their ability and level in educational scientific research are "high"; $37.3 \%$ of teachers (1678) think their ability and level in educational scientific research is "ordinary"; $35 \%$ of teachers (1575) think their ability and level in educational scientific research is "low". It shows most primary and secondary school teachers think lowly of their ability and level in educational scientific research "Table XI". 
TABLE XII. The Situation That Primary and SeCOndary School TEACHERS PUBLISH ACADEMIC PAPERS

\begin{tabular}{|l|l|l|l|l|}
\hline Option & $\begin{array}{l}\text { Publish } \\
\text { papers on } \\
\text { professional } \\
\text { academic } \\
\text { journals with } \\
\text { public issue }\end{array}$ & $\begin{array}{l}\text { Publish } \\
\text { papers on } \\
\text { professional } \\
\text { academic } \\
\text { journals with } \\
\text { internal issue }\end{array}$ & $\begin{array}{l}\text { Have written } \\
\text { scientific } \\
\text { papers but } \\
\text { haven't } \\
\text { published yet }\end{array}$ & $\begin{array}{l}\text { Cannot } \\
\text { write } \\
\text { academic } \\
\text { papers }\end{array}$ \\
\hline $\begin{array}{l}\text { Number } \\
\text { of } \\
\text { persons }\end{array}$ & 693 & 981 & 2088 & 738 \\
\hline $\begin{array}{l}\text { Proportio } \\
\text { n }\end{array}$ & $15.4 \%$ & $21.8 \%$ & $46.4 \%$ & $16.4 \%$ \\
\hline
\end{tabular}

$15.4 \%$ of teachers (693) can "publish papers on professional academic journals with public issue"; $21.8 \%$ of teachers (981) can "publish papers on professional academic journals with internal issue"; $46.4 \%$ of teachers (2088) "have written scientific papers but haven't published yet"; $16.4 \%$ of teachers (738) "cannot write academic papers". The publication of academic papers is an important and direct symbol to judge primary and secondary school teachers' ability and level in the educational scientific research. The data show most primary and secondary school teachers cannot write or publish professional academic papers and their ability and level in the educational scientific research is low "Table XII".

TABLE XIII. WAYS USED BY THE PRIMARY AND SECONDARY SCHOOL TEACHERS IN EDUCATIONAL SCIENTIFIC RESEARCH

\begin{tabular}{|c|c|c|c|c|}
\hline Option & $\begin{array}{l}\text { Can do } \\
\text { the } \\
\text { education } \\
\text { al } \\
\text { scientific } \\
\text { research } \\
\text { independe } \\
\text { ntly }\end{array}$ & $\begin{array}{l}\text { Do the } \\
\text { education } \\
\text { al } \\
\text { scientific } \\
\text { research } \\
\text { through } \\
\text { cooperatio } \\
\mathrm{n} \text { with } \\
\text { colleagues }\end{array}$ & $\begin{array}{c}\text { Do the } \\
\text { educational } \\
\text { scientific } \\
\text { research } \\
\text { under the } \\
\text { guidance of } \\
\text { experts }\end{array}$ & $\begin{array}{l}\text { Cannot do the } \\
\text { educational } \\
\text { scientific } \\
\text { research } \\
\text { independently }\end{array}$ \\
\hline $\begin{array}{l}\text { Number } \\
\text { of } \\
\text { persons }\end{array}$ & 1719 & 1471 & 963 & 347 \\
\hline $\begin{array}{l}\text { Proportio } \\
\text { n }\end{array}$ & $38.2 \%$ & $32.7 \%$ & $21.4 \%$ & $7.7 \%$ \\
\hline
\end{tabular}

$38.2 \%$ of teachers (1719) "can do the educational scientific research independently"; $32.7 \%$ of teachers (1471) "do the educational scientific research through cooperation with colleagues"; $21.4 \%$ of teachers (963) "do the educational scientific research under the guidance of experts"; $7.7 \%$ of teachers (347) "cannot do the educational scientific research independently". It shows most primary and secondary school teachers cannot do the educational scientific research without the guidance and help of others. It also reflects they lack the ability in educational scientific research "Table XIII".

TABLE XIV. ACTUAL BEHAVIORS OF PRIMARY AND SECONDARY SCHOOL TEACHERS IN EDUCATIONAL SCIENTIFIC RESEARCH

\begin{tabular}{llll}
\hline Option & Often write & Occasionally write & Don't write \\
\hline $\begin{array}{l}\text { Number of } \\
\text { persons }\end{array}$ & 594 & 1062 & 2844 \\
Proportion & $13.2 \%$ & $23.6 \%$ & $63.2 \%$ \\
\hline
\end{tabular}

In regard to the actual behaviors of primary and secondary school teachers in educational scientific research (mainly bases on whether they can write papers in the educational scientific research), $13.2 \%$ of teachers (594) "often write"; $23.6 \%$ of teachers (1062) "occasionally write"; $63.2 \%$ of teachers (2844) "don't write". It shows most teachers don't work on the educational scientific research consciously because of the weak atmosphere in schools "Table XIV".

\section{Advantages and Limitations of the Primary and Secondary School Teachers in Working on the Educational Scientific Research}

TABLE XV. ADVANTAGES AND LIMITATIONS OF THE PRIMARY AND SECONDARY SCHOOL TEACHERS IN WORKING ON THE EDUCATIONAL SCIENTIFIC RESEARCH

\begin{tabular}{|c|c|c|c|c|}
\hline Option & $\begin{array}{l}\text { Experience } \\
\mathrm{d} \quad \text { in } \\
\text { educational } \\
\text { practice }\end{array}$ & $\begin{array}{l}\text { Closely } \\
\text { contact } \\
\text { with } \\
\text { students } \\
\text { and know } \\
\text { them well }\end{array}$ & $\begin{array}{l}\text { Be } \\
\text { familiar } \\
\text { with the } \\
\text { teaching } \\
\text { contents }\end{array}$ & $\begin{array}{l}\text { Have good } \\
\text { theoretical } \\
\text { accomplishm } \\
\text { ent of } \\
\text { education }\end{array}$ \\
\hline $\begin{array}{l}\text { Number of } \\
\text { persons }\end{array}$ & 1512 & 1269 & 1165 & 554 \\
\hline Proportion & $33.6 \%$ & $28.2 \%$ & $25.9 \%$ & $12.3 \%$ \\
\hline
\end{tabular}

$33.6 \%$ of teachers (1512) think they are "experienced in educational practice"; $28.2 \%$ of teachers (1269) think they "closely contact with students and know them well"; $25.9 \%$ of teachers (1165) think they "are familiar with the teaching contents"; $12.3 \%$ of teachers (554) think they "have good theoretical accomplishment of education". It shows the biggest advantage of the primary and secondary school teachers is the rich teaching experience in educational scientific research, which cannot do without the educational practice "Table XV".

TABLE XVI. LiMITATIONS AND DiFFICULTIES OF THE PRIMARY AND SECONDARY SCHOOL TEACHERS IN WORKING ON THE EDUCATIONAL SCIENTIFIC RESEARCH

\begin{tabular}{lllll}
\hline Option & $\begin{array}{l}\text { Lack } \\
\text { of } \\
\text { time }\end{array}$ & $\begin{array}{l}\text { Lack of } \\
\text { research } \\
\text { data }\end{array}$ & $\begin{array}{l}\text { Lack of } \\
\text { experts' } \\
\text { guidance }\end{array}$ & $\begin{array}{l}\text { Have low theoretical } \\
\text { accomplishment of } \\
\text { education and don't } \\
\text { understand the } \\
\text { knowledge and skills } \\
\text { of educational } \\
\text { scientific research }\end{array}$ \\
\hline $\begin{array}{l}\text { Number of } \\
\text { persons } \\
\text { Proportion }\end{array}$ & 859 & 779 & 1656 & 1206 \\
\hline
\end{tabular}

$19.1 \%$ of teachers (859) think "lack of time"; $17.3 \%$ of teachers (779) think "lack of research data"; $36.8 \%$ of teachers (1656) think "lack of experts' guidance"; $26.8 \%$ of teachers (1206) think they "have low theoretical accomplishment of education and don't understand the knowledge and skills of educational scientific research". It reflects the primary and secondary school teachers working on the educational scientific research often encounter many problems and difficulties, the most prominent of which is the lack of experts' guidance and the knowledge and skills of educational scientific research and the low theoretical accomplishment in education "Table XVI". 
We can draw the following conclusions according to the above investigations. With the reform and development of education, especially under the influence of new curriculum reform in basic education, primary and secondary school teachers have further understood the meaning and effect of educational scientific research. They have stronger consciousness and clear motivation in working on the educational scientific research and more behaviors of research in teaching process. They gradually accept the opinions that "regard the familiar teaching work with the attitudes of research and exploration" and "let research become a way of working and life".

At present, primary and secondary school teachers have weak consciousness, low ability and quality in the educational scientific research. They have backward educational concept, low theoretical accomplishment in education, weak consciousness in research of education and lack ability and obvious achievements as well as emotional experience in the educational scientific research. The reinforcement of primary and secondary school teachers' consciousness in the educational scientific research doesn't conform to their low quality in the educational scientific research. On one hand, they gradually realize the meaning and value and have a sense of urgency in working on the educational scientific research; on the other hand, because they have low quality in the educational scientific research, penetrating contradictions exist between they want to do the research and they cannot do the research. Currently, the low quality of primary and secondary school teachers in the educational scientific research has become a "bottleneck" in impeding their professional development and the improvement of teaching quality. The improvement of primary and secondary school teachers' ability in the educational scientific research has become an important mission of the current educational reform and development and the continuing education and training of teachers. The primary and secondary school teachers have advantages, weaknesses and limitations in working on the educational scientific research. In comparison, the weaknesses are more prominent. Therefore, the primary and secondary school teachers should adopt good points and avoid shortcomings in working on the educational scientific research.

\section{SUgGestions AND STRATEGIES FOR THE PRIMARY AND SECONDARY SCHOOL TEACHERS TO DEVELOP THE EDUCATIONAL SCIENTIFIC RESEARCH}

With the continuous development of new curriculum reform, it has higher theoretical and practical requirements for the primary and secondary school teachers and emphasizes the change of teachers' role. It means the teachers should have "new view of teacher, advanced educational idea and flexible teaching methods, comprehensive professional quality and noble professional ethnics". Teachers' educational scientific research becomes an effective way to solve problems and helps teachers to adapt to the role faster and more accurately and meet the challenges. At the meantime, it is also an important part of professional quality and the route teachers must take to accelerate the specialized growth and realize selftranscendence. At present, it has become the requirement of the times. The educational scientific research can improve the professional quality of teachers, teaching quality and create learning atmosphere as well as form learning organization to adapt to the continuous external environment. More and more schools have carried out diversified activities related to the educational scientific research and an increasing number of teachers participate in it. According to the above research analysis, the following suggestions are proposed.

\section{A. Awaken the Self-awareness of Scientific Research: Base on the Requirements of Lifelong Learning and \\ Development}

Teachers' self-awareness of scientific research is the origin of educational scientific research. Different awareness of scientific research will lead to two different development directions, namely "the usefulness of scientific research" and "the uselessness of scientific research". It is of vital importance for teachers to establish the awareness of scientific research about lifelong learning and development, which can help novice teachers to adapt to the role and find the direction, experienced teachers to more effectively solve the problems of "development bottleneck", backbone teachers to pinpoint the research direction, expert teachers to improve the development space, and teachers about to retire to embody more personal values. Therefore, the primary and secondary school teachers should:

Firstly, set up the idea of "mutual promotion of educational scientific research and teaching"; strengthen the belief of "the usefulness of scientific research" and find opportunities and possibilities of scientific research at any moment; rely on the knowledge to explore and the scientific research methods to solve problems in teaching; seize the opportunity to participate in and research the topics on school level and accelerate the specialized growth through mutual promotion of scientific research and teaching.

Secondly, make long-term plans for the scientific research and strengthen the "learning awareness" and "problem consciousness" of teaching and scientific research. Teachers should apply the idea of "scientific research" to teaching and solve practical problems. Make long-term scientific research plan and the target of vocational development, determine the phased tasks and check regularly. Make use of the platforms provided by the school and participate in more training of scientific research and learn richer knowledge and methods of scientific research.

Thirdly, form reasonable and lasting motivation of scientific research, which is the power source of teachers' educational scientific research. Many motivations of scientific research have been summarized according to the investigation on the primary and secondary school teachers in Xin'an County. However, the motivation of "scientific research utilitarianism" cannot exist because it is deficiency need and will disappear after being met. Therefore, it is necessary to form the motivation of scientific research under the promotion of "interest orientation" and "achievement motivation", which belongs to the "growth motivation", bringing powerful internal motivation for teachers' educational scientific research and helping them to turn to the "research-based" role. Continuously strengthen the "awareness of reconsideration" 
and internalize it into activities of scientific research. Teachers should meet the requirements of new curriculum reform as researchers.

\section{B. Reserve the Internal Scientific Research Knowledge: Base on the Real Demand of Teaching and Practice}

The reserve and update of scientific research knowledge can strongly promote teachers' educational scientific research. Therefore, it is necessary to strengthen the reserve of teachers' scientific research knowledge and form diversified knowledge structure. Firstly, reserve solid and systematic cultural and theoretical knowledge. Teachers should develop the habit of accumulating knowledge in teaching and life, including the solid knowledge related to the discipline as well as extensive cultural knowledge and theoretical knowledge of scientific research, so as to help the self-development and effectively stimulate students' thirst for knowledge. Secondly, grasp basic methods to reserve and apply the scientific research. Teachers should research through flexibly using the literature material law, case study method, questionnaire method, observation method and experiential summary method. They should also use it properly according to the specific needs in the quantitative research.

\section{Improve the Ability in Independent Scientific Research: Base on the Urgent Demands of Research-oriented Teachers}

Teachers' internal ability of educational scientific research is one of the important elements that influence the achievements in scientific research, and it needs a long time to train, improve and internalize. Firstly, develop the way of thinking and the method of "find problems to deal with problems". Develop the consciousness of problems, find "real" problems in teaching practice and find out ways to solve problems according to the educational phenomenon. And then choose and deal with problems through self-exploration, communication with companions and consulting experienced teachers.

Secondly, train the innovation ability. Teachers need to have the courage to break through and the perseverance to explore. In teaching practice, the innovation ability of scientific research should be trained in finding and dealing with problems. Teachers can try new methods and learn deeper theoretical knowledge according to the research needs. Thirdly, train the ability in organizing the scientific research, covering the demonstration of the selected topics, project design, research implementation and data analysis as well as the information processing. It is conducive to teachers' long-term development of professional career to comprehensively train the ability in organizing the scientific research. Finally, train the ability to participate in and organize the scientific research team. The scientific research team plays a big role in teachers' growth, guiding the scientific research direction of teachers and providing power and cohesion of organization under the current situation that the structure of teachers' ability in scientific research is incomplete with large improvement space; it can further improve the young teachers' enthusiasm and collaboration in scientific research, because there are specific division of labor and cooperation in the team, it is more helpful to form a harmonious atmosphere of scientific research; meanwhile, it helps the backbone teachers to acquire "sense of achievement" and "sense of belonging". The establishment of scientific research team should also adhere to the principle of "reasonable structure, complement of advantages and combination of abilities and strong feasibility".

\section{Develop the Subjective Attitude of Scientific Research: \\ Pursuit on the Basis of Professional Ethnics and Beliefs}

Teachers' attitude toward the scientific research reflects in their mentality and action and embodies their pursuit of the professional ethics and beliefs. According to the investigation on teachers in the primary school of Xingfu Road of Zhengzhou City and the 53rd secondary school of Zhengzhou, it shows problems like "lack of the power of scientific research and the perseverance to insist and study and the preciseness" still exist. At present, the "scientific research complex" exists: One kind of helplessness (papers are the necessity in conferring of academic titles); two kinds of escape (the scientific research is complicated and an extra burden; the reflection is the scientific research; three kinds of entanglement (too busy to write; want to write but the ability is poor; is writing but has no innovation). It reduces the quality of scientific research and teachers' quality and level in the scientific research. Therefore, teachers should develop a rigorous, persistent, studious and shared attitude toward the scientific research as well as the noble-minded moral, strictly pursue the normalization and originality of scientific research, and meanwhile develop a normative scientific research behavior, persistent and tenacious attitudes toward the scientific research.

\section{CONCLUSION}

The primary and secondary school teachers shoulder heavy responsibilities in the development of educational scientific research in middle and primary schools, in order to promote their professional development and the development of curriculum and students. It needs continuous exploration about how to eliminate the false and retain the true, set up an effective mode of activities in the educational scientific research and how to promote the enhancement of teachers' quality in the educational scientific research, which is the first and foremost as well as the most essential part. Teachers should establish correct cognition and have a proper level of motivation as well as basic knowledge and ability in the educational scientific research. Only in this way can problems in the educational scientific research of the middle and primary schools of our country be solved thoroughly and can the true value of it be realized.

\section{REFERENCES}

[1] Wang Zede, Zhao Shangbo. Research on the Problems in the Construction of Teaching Staff in Rural Areas of Our Country at Present and Countermeasures [J], Education Exploration, 2011,(8)

[2] Fan Xianzuo, Zeng Xin, Guo Qingyang. The Balanced Development of Compulsory Education and the Construction of Primary and Secondary school Teaching Staff in Rural Areas [J], Education and Economy, 2013 (6) 
[3] Fan Xianzuo, Guo Qingyang, Zhao Dan. The Balanced Development of Compulsory Education and the Construction of Teaching School in Rural Areas [J], Educational Research, 2011, (9)

[4] Zhao Dan, Wu Hongchao. Review on the Function of Rural Small Schools from the Global Angle [J], Exploring Education Development, 2012, (3) 